\title{
Extract of Sporoderm-Broken Germinating Spores of Ganoderma lucidum Activates Human Polymorphonuclear Neutrophils via the P38 Mitogen-activated Protein Kinase Pathway
}

\author{
Pei-Yu Hsu' ${ }^{1}$, MD; Jiun-Liang Chen ${ }^{1,2}$, MD; Hsing-Yu Chen ${ }^{1}, \mathrm{MD}$; \\ Sien-Hung Yang ${ }^{1,2}, \mathrm{MD}, \mathrm{PhD}$
}

Background: Ganoderma lucidum (G. lucidum) has been used in traditional Chinese medicine for thousands of years because of its immunomodulatory properties. It is believed that $G$. lucidum enhances the human immune response by improving the function of human polymorphonuclear neutrophils (PMNs); nevertheless, the actual mechanism by which $G$. lucidum acts on human PMNs remains unknown. In this study, we investigated the molecular pathways through which G. lucidum activates human PMNs.

Methods: The phagocytic activity of PMNs was evaluated with and without treatment with the extract of sporoderm-broken germinating spores of G. lucidum. The same activity was measured after G. lucidum treatment with or without p38 mitogen-activated protein kinase (p38 MAPK) inhibitor. The activation of p38 MAPK was also evaluated with or without treatment with the extract of sporoderm-broken germinating spores of G. lucidum.

Results: In this study, we found that the extract of G. lucidum enhanced the phagocytic activity of PMNs in a dose-dependent manner, but this response was attenuated by treatment with SB203580, a p38 MAPK inhibitor. The extract of $G$. lucidum also enhanced activation of p38 MAPK in a dose-dependent manner.

Conclusion: These results clearly show that the extract of G. lucidum can modulate human immunity by activating human PMNs via the p38 MAPK pathway. These results may be of clinical importance to doctors of traditional Chinese medicine.

(Chang Gung Med J 2012;35:140-7)

Key words: traditional Chinese medicine, Ganoderma lucidum (G. lucidum), polymorphonuclear neutrophils (PMNs), p38 mitogen-activated protein kinase (p38 MAPK)

Ganoderma lucidum (G. lucidum), also called cine that has been widely used in traditional Chinese medicine for thousands of years because of its

From the 'Department of Traditional Chinese Medicine, Chang Gung Memorial Hospital at Taoyuan, Chang Gung University College of Medicine, Taoyuan, Taiwan; ${ }^{2}$ School of Traditional Chinese Medicine, College of Medicine, Chang Gung University, Taoyuan, Taiwan.

Received: Feb. 10, 2011; Accepted: Sep. 29, 2011

Correspondence to: Dr. Sien-Hung Yang, Department of Traditional Chinese Medicine, Chang Gung Memorial Hospital at Taoyuan. 123, Dinghu Rd., Jiolu Village, Gueishan Township, Taoyuan County 333, Taiwan (R.O.C.) Tel: 886-3-3196200 ext. 2611 ; Fax: 886-3-3298995; E-mail: dryang@cgmh.org.tw 
immunomodulatory properties. The bioactivity of $G$. lucidum has been elucidated by many authors and includes such diverse properties as anti-HIV, ${ }^{(1)}$ antiherpetic, ${ }^{(2)}$ anticoagulant, ${ }^{(3)}$ antiangiogenic, ${ }^{(4)}$ antiandrogenic, ${ }^{(5)}$ and antitumor activities. ${ }^{(6-9)}$ The immunomodulatory function of G. lucidum is currently of great interest worldwide. Mechanistic studies have shown that the antitumor activity of G. lucidum is mediated through immune system effectors such as natural killer cells, macrophages, and $\mathrm{T}$ and $\mathrm{B}$ lymphocytes. ${ }^{(10-13)}$

Spores are the medically essential part of $G$. lucidum and are rich in polysaccharides, triterpenes and other bioactive substances. In our previous pilot study, we found that the sporoderm-broken germinating spores of G. lucidum modulated the phagocytic activity of polymorphonuclear neutrophils (PMNs). However, the mechanism underlying this activity remains unclear. Because human PMNs play an important role in inflammation and are the first line of defense against microbial invasion, we were interested in studying the effects of G. lucidum on human PMNs.

P38 mitogen-activated protein kinase (p38 MAPK) is an important mediator of PMN function in inflammation. It is the mammalian homologue of the yeast HOG kinase and participates in a cascade that controls cellular responses to cytokines and stress. Inflammatory stimuli such as lipopolysaccharide, tumor necrosis factor and interleukin-1 are the major inducers of p38 MAPK. ${ }^{(14)}$

In this study, we employed an in vitro system to evaluate the immunomodulatory effects of the extract of sporoderm-broken germinating spores of G. lucidum on human PMNs. We investigated the effects of G. lucidum and p38 MAPK inhibitors on the phagocytic activity of human PMNs and evaluated the influence of G. lucidum on the activation of p38 MAPK. These results will aid in elucidating the immunomodulatory mechanism of G. lucidum in human PMNs and in determining the clinical importance of G. lucidum in traditional Chinese medicine.

\section{METHODS}

\section{Plants and spores}

G. lucidum was donated by Chang Gung Biotechnology Co. Ltd. The sporoderm of the germinating spores was broken with an efficiency of up to
99.8\% before the study. The spores of G. lucidum (15 g samples) were extracted with $\mathrm{H}_{2} \mathrm{O}$ first at room temperature (RT) $(400 \mathrm{ml} \times 3)$ and then at $70^{\circ} \mathrm{C}(400$ $\mathrm{ml} \times 3$ ), separately. The filtrates were concentrated to yield brown syrups (2.31 g).

\section{Isolation of PMNs from the peripheral blood of healthy individuals}

Nine healthy volunteers, 6 women and 3 men, from 26 to 35 years old, without major systemic diseases, malignancy or hereditary diseases and without a history of drug or health food intake in the past 3 months, were enrolled in this study. Heparinized venous blood obtained from each individual was mixed with one-fourth volume of $4.5 \%$ dextran solution (molecular weight: 500,000) and incubated for 30 min at RT. The leukocyte-enriched supernatants were collected and diluted with equal volumes of Hanks' balanced salt solution. After Ficoll-Hypaque (specific gravity 1.077) density gradient centrifugation at $150 \times \mathrm{g}$ for $25 \mathrm{~min}$, PMNs were obtained from the bottom. The PMNs were washed 3 times and suspended in $10 \%$ fetal bovine serum (FBS) in RPMI1640 (10\% FBS-RPMI). The cells were counted and the suspensions adjusted to $2 \times 10^{6}$ cells $/ \mathrm{ml}$. The viability of the cells was assessed by trypan blue dye exclusion and was $>95 \%$ for each experiment.

\section{Measurement of phagocytic activity of PMNs with or without the extract of $\boldsymbol{G}$. lucidum}

The phagocytic activity of PMNs was measured as previously described. ${ }^{(15)}$ Briefly, fluoresbrit carboxylate microspheres $(0.75 \mu \mathrm{m}$, Polysciences Inc., Warington, PA, U.S.A.) were opsonized with fresh normal serum at $37^{\circ} \mathrm{C}$ for $45 \mathrm{~min}$ before use. One hundred microliters of freshly isolated PMN ( $2 \mathrm{x}$ $106 / \mathrm{ml}$ ) was incubated with $10 \mu \mathrm{l}$ of opsonized beads $(2 \times 109 / \mathrm{ml})$ at $37^{\circ} \mathrm{C}$ for $30 \mathrm{~min}$ in the presence of 40 $\mu \mathrm{l}$ of culture medium (as a negative control) or pretreated various concentrations of G. lucidum extract for $10 \mathrm{~min}$.

The PMNs were collected by centrifugation at $300 \mathrm{xg}$ for $10 \mathrm{~min}$ and washed 3 times to remove the non-phagocytosed beads. The percentage (\%) and mean fluorescence intensity $\left(\mathrm{MFI}^{*}\right)$ of bead-engulfing PMNs (phagocytosis-positive) were measured by flow cytometry on a FAXS 440 instrument (BectonDickinson, San Jose, CA, U.S.A.). 
Measurement of phagocytic activity of PMNs treated with the extract of G. lucidum with or without p38 MAPK inhibitor

The same method was used to measure the phagocytic activity of PMNs treated with various concentration of $G$. lucidum extract with or without SB203580 as an inhibitor of p38 MAPK. The concentration of the inhibitor used was specific for the kinase as previously reported. ${ }^{(16)}$

\section{Western blot analysis of p38 MAPK activation}

The isolated PMNs were treated with various concentrations of G. lucidum extract for $7.5 \mathrm{~min}$. A pretest study had been done with another 7 healthy volunteers who did not have systemic diseases, malignancy or hereditary diseases and no history of drug or health food intake in the past 3 months. This study revealed the best effect on p38 MAPK activation was at 7.5 min under the same concentration of G. lucidum treatment. Totally, 3 of the original 9 volunteers participated in the phagocytosis study ( 2 woman 28 and 33 years old and 1 man 29 years old) were excluded from this experiment because the amounts of isolated PMNs were not high enough in these 3 individuals. Total protein concentrations of the extracts were measured by BCA protein assay (Beyotime, Jiangsu, China), according to the manufacturer's instructions. Equal amounts of leukocyte extracts $(50 \mu \mathrm{g}$ protein) were then subjected to sodium dodecyl sulfate-polyacrylamide gel electrophoresis in a $10 \%$ gel. The separated proteins were blotted onto a polyvinylidene fluoride membrane. The membrane was blocked at RT for $1 \mathrm{~h}$ in $5 \%(\mathrm{w} / \mathrm{v})$ dry skim milk and incubated at $4{ }^{\circ} \mathrm{C}$ overnight with a 1:1000 dilution of the desired primary antibody. Primary antibodies used were rabbit antibodies specific for p38 MAPK, phospho-p38 MAPK, and $\beta$ actin (Cell Signaling, Beverly, MA, U.S.A.). The addition of the primary antibody was followed by incubation at RT for $1 \mathrm{~h}$ with a 1:1000 dilution of anti-rabbit IgG secondary antibody conjugated with horseradish peroxidase (Beyotime). The peroxidase reaction was visualized by an enhanced chemiluminescence method with an EZ-ECL chemiluminescence detection kit (Biological Industries, Kibbutz Beit Haemek, Israel). The relative intensities of the protein bands were quantified by scanning densitometry in a Bio-Rad (Shanghai, China) Fluor-S multiimager using the Quantity One program. Relative expression levels of the target protein were expressed as target protein (p38 MAPK or phosphorylated p38 MAPK $) / \beta$-actin ratios.

\section{Statistical analysis}

Results were presented as median (inter-quartile range). The differences between groups were analyzed using the non-parametric Wilcoxon signedrank test, and a " $p$ " value of less than 0.05 was considered statistically significant.

\section{RESULTS}

\section{Phagocytic activity of PMNs with or without the extract of G. lucidum}

The PMNs were pretreated with various concentrations of G. lucidum extract for $10 \mathrm{~min}$ before incubation with the opsonized beads at $37^{\circ} \mathrm{C}$ for $30 \mathrm{~min}$. The phagocytic activities of PMNs with or without G. lucidum treatment were determined by flow cytometry using $\mathrm{MFI}^{\#}$ as a measurement of PMN phagocytic activity. The PMN phagocytic activity was significantly enhanced after treatment with $G$. lucidum at concentrations of $40 \mathrm{mg} / \mathrm{ml}$ and $80 \mathrm{mg} / \mathrm{ml}$ (both $p<0.05$ ) (Table 1). When the concentration of

Table 1. Effects of the Extract of G. lucidum with or without P38 MAPK Inhibitor on PMN Phagocytic Activity among 9 Healthy Volunteers (6 women and 3 men from 26 to 35 years old)

\begin{tabular}{|c|c|c|c|c|}
\hline $\begin{array}{l}\text { Concentration } \\
\text { of } G . \text { lucidum }\end{array}$ & $\begin{array}{c}\text { Phagocytic } \\
\text { activity } \\
\left(\mathrm{MFI}^{\sharp}\right) \% \\
\mathrm{~N}=9, \\
\text { median } \\
\text { (inter-quartile } \\
\text { range) }\end{array}$ & $\begin{array}{l}\text { Phagocytic } \\
\text { activity } \\
\left(\mathrm{MFI}^{*}\right) \% \\
\text { with p38 } \\
\text { MAPK } \\
\text { inhibitor } \\
\text { treatment }\end{array}$ & $* p$ value & ${ }^{\dagger} p$ value \\
\hline $0 \mathrm{mg} / \mathrm{ml}$ & $42.92(10.25)$ & $42.88(19.06)$ & & \\
\hline $40 \mathrm{mg} / \mathrm{ml}$ & $54.02(16.875)$ & $50.07(6.705)$ & 0.021 & 0.015 \\
\hline $80 \mathrm{mg} / \mathrm{ml}$ & $57.22(12.27)$ & $54.12(11.79)$ & 0.015 & 0.008 \\
\hline $100 \mathrm{mg} / \mathrm{ml}$ & $59.16(8.9)$ & 48.15 (9.67) & 0.086 & 0.011 \\
\hline
\end{tabular}

Abbreviations: G. lucidum: Ganoderma lucidum; PMN: polymorphonuclear neutrophil; MFI": mean fluorescence intensity; *: by Wilcoxon signed-rank test, comparing PMN phagocytic activities using various concentrations of $G$. lucidum with $0 \mathrm{mg} / \mathrm{ml}$ of $G$. lucidum as the negative control. $\uparrow$ : by Wilcoxon signed-rank test, comparing PMN phagocytic activities of $G$. lucidum using the same concentrations with or without p38 MAPK inhibitor. 
G. lucidum was increased to $100 \mathrm{mg} / \mathrm{ml}$, the PMN phagocytic activity was not altered relative to the negative control.

Phagocytic activity of PMNs treated with $G$. lucidum extract with or without p38 MAPK inhibitor

The phagocytic activity of PMNs treated with G. lucidum extract with or without an inhibitor of p38 MAPK was determined using MFI $^{*}$ as a measurement of PMN phagocytic activity. The PMN phagocytic activity was significantly attenuated by p38 MAPK inhibitor treatment at G. lucidum extract concentrations of $40 \mathrm{mg} / \mathrm{ml}$ and $80 \mathrm{mg} / \mathrm{ml}$ (both $p<$ 0.05) (Table 1).

\section{Activation of p38 MAPK as shown by western blot analysis}

Western blot analysis was performed to measure p38 MAPK activation. The activation rate was determined by calculating the ratio of phosphorylated p38 MAPK to p38 MAPK for each sample. Under the same concentration of G. lucidum treatment, the best effect on p38 MAPK activation was at $7.5 \mathrm{~min}$ (Table 2). By using this assay, we found that treatment with $G$. lucidum extract for 7.5 min at concentrations of $40 \mathrm{mg} / \mathrm{ml}$ and $80 \mathrm{mg} / \mathrm{ml}$ significantly increased p38 MAPK activation $(p<0.05)$ (Table 3, Fig. 1).

Table 2. Time-course Effects of the Extract of G. lucidum on p38MAPK Activation among 7 Healthy Volunteers (4 women and 3 men from 24 to 41 years old)

\begin{tabular}{ccc}
\hline $\begin{array}{l}\text { Treatment time } \\
\text { of } \begin{array}{l}\text {. lucidum } \\
(40 \mathrm{mg} / \mathrm{ml})\end{array}\end{array}$ & $\begin{array}{c}\text { Activation ratio } \\
\text { (p-p38MAPK/p38MAPK) } \mathrm{N}=7, \\
\text { median (inter-quartile range) }\end{array}$ & $* p$ value \\
\hline $0 \mathrm{~min}$ & $0.777(1.034)$ & 0.611 \\
$1.0 \mathrm{~min}$ & $0.813(0.882)$ & 0.865 \\
$2.5 \mathrm{~min}$ & $0.811(0.881)$ & 0.235 \\
$5.0 \mathrm{~min}$ & $0.853(1.174)$ & 0.018 \\
$7.5 \mathrm{~min}$ & $0.879(1.228)$ & 0.396 \\
$10 \mathrm{~min}$ & $0.925(0.914)$ & 0.175 \\
$15 \mathrm{~min}$ & $0.863(1.032)$ & $\mathrm{P}$
\end{tabular}

Abbreviations: p-p38MAPK: phosphorylated- p38 mitogenactivated protein kinase; *: by Wilcoxon signed-rank test, using 0 min of G. lucidum treatment as the negative control.

\section{DISCUSSION}

G. lucidum, a traditional Chinese medicine, has long been used in Asian societies to promote health and treat various diseases. Many studies have been performed on the bioactivities of this herbal medicine, especially on its immunomodulatory activity. The bioactive substances from G. lucidum had previously been shown to modulate the immune response by promoting cytokine production by immune

Table 3. Effects of the Extract of G. lucidum on p38MAPK Activation among 6 of the 9 Original Healthy Volunteers

\begin{tabular}{lcc}
\hline $\begin{array}{l}\text { Concentration } \\
\text { of } G \text {. lucidum }\end{array}$ & $\begin{array}{c}\text { Activation ratio } \\
\text { (p-p38MAPK/p38MAPK) }\end{array}$ & $* p$ value \\
\hline $0 \mathrm{mg} / \mathrm{ml}$ median (inter-quartile range) & $0.468(0.556)$ & \\
$40 \mathrm{mg} / \mathrm{ml}$ & $0.496(0.687)$ & 0.028 \\
$80 \mathrm{mg} / \mathrm{ml}$ & $0.506(0.746)$ & 0.046 \\
$100 \mathrm{mg} / \mathrm{ml}$ & $0.507(0.708)$ & 0.463 \\
$120 \mathrm{mg} / \mathrm{ml}$ & $0.475(0.878)$ & 0.249 \\
$140 \mathrm{mg} / \mathrm{ml}$ & $0.487(0.730)$ & 0.249 \\
\hline
\end{tabular}

Abbreviations: p-p38MAPK: phosphorylated- p38 mitogenactivated protein kinase; *: by Wilcoxon signed-rank test, using 0 $\mathrm{mg} / \mathrm{ml}$ of $G$. lucidum as the negative control; †: negative value.

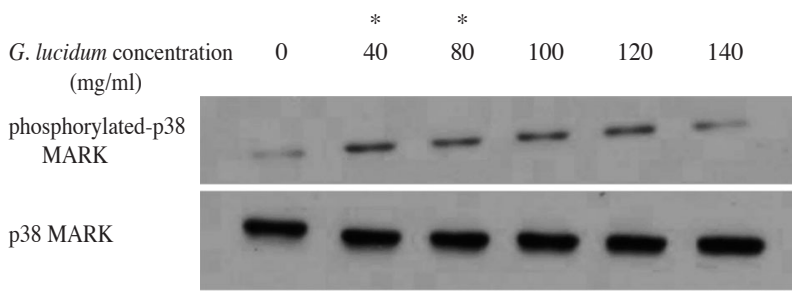

Fig. 1 Effects of the Extract of G. lucidum on P38 MAPK Activation. Western blot analysis performed to measure p38 MAPK activation by treatment with various concentrations of G. lucidum. p38 MAPK has significantally increased activation with $G$. lucidum treatment for $7.5 \mathrm{~min}$ at concentrations of $40 \mathrm{mg} / \mathrm{ml}(p=0.028)$ and $80 \mathrm{mg} / \mathrm{ml}(p=0.046)$. The activation rate was determined by calculating the ratio of phosphorylated p38 MAPK to p38 MAPK for each sample. Abbreviations used: G. lucidum: Ganoderma lucidum; p38 MAPK: p38 mitogen-activated protein kinase; *: $p<0.05$ 
cells ${ }^{(17,18)}$ preventing oxidative injury, ${ }^{(19)}$ enhancing the function of dendritic cells, ${ }^{(20)}$ and activating lymphocytes. ${ }^{(10,13)}$ Signaling pathways influenced by these bioactive substances have also been investigated. Polysaccharides from G. lucidum can induce the activation and maturation of human dendritic cells by activating the NF-KB and p38 MAPK pathways, ${ }^{(21)}$ and can inhibit Fas-mediated apoptosis by activating Akt-regulated signaling pathways, ${ }^{(22)}$ whereas triterpenes from G. lucidum exert anti-inflammatory and anti-proliferative effects by inhibiting NF- $\mathrm{\kappa B}$ and AP-1 signaling in lipopolysaccharide-activated macrophages. ${ }^{(23)}$

In recent years, many chronic diseases such as allergic rhinitis, ${ }^{(15)}$ arthritis, ${ }^{(14,24)}$ diabetes mellitus, ${ }^{(25)}$ heart diseases, ${ }^{(26)}$ hypertension ${ }^{(27)}$ and cancer, ${ }^{(28)}$ have been reported to be related to inflammation. Human PMNs are well known to mediate inflammation and play an important role in the host defense against microbial infection. The functional activities of PMNs include chemotaxis, phagocytosis, secretion of anti-microbial agents, and generation of reactive oxygen intermediates. ${ }^{(29)}$ Because the immunomodulatory function of G. lucidum is of great interest owing to its relevance to many diseases, we wished to study the effects of G. lucidum on human PMNs.

Previous reports had shown that polysaccharides from G. lucidum enhance the phagocytic activity of human PMNs and increase PMN migration by chemotactic assay. ${ }^{(30)}$ p38 MAPK was found to be an important activator of PMN chemotaxis and phagocytosis. ${ }^{(16,31)}$ In addition, exposure to G. lucidumderived polysaccharide enhanced the activities of some immune mediators such as protein kinase $\mathrm{C}$, p38 MAPK, Hck, and Lyn in a time-dependent manner. $^{(30)}$

In this study we focused on the effects of $G$. lucidum on human PMNs via the p38 MAPK pathway. Our data indicated that the extract of $G$. lucidum at concentrations of $40 \mathrm{mg} / \mathrm{ml}$ and $80 \mathrm{mg} / \mathrm{ml}$ enhanced the phagocytic activity of PMNs in a dosedependent manner. Furthermore, the increased phagocytic activity of PMNs treated with G. lucidum at $40 \mathrm{mg} / \mathrm{ml}$ and $80 \mathrm{mg} / \mathrm{ml}$ was significantly attenuated by treatment with $\mathrm{p} 38$ MAPK inhibitor (both $p$ $<0.05)$.

For further confirmation of the effects of $G$. lucidum on the p38 MAPK pathway, we measured the G. lucidum-mediated activation of p38 MAPK by western blot analysis. The activation of p38 MAPK was also enhanced in a dose-dependent manner at $G$. lucidum concentrations of $40 \mathrm{mg} / \mathrm{ml}$ and $80 \mathrm{mg} / \mathrm{ml}$, consistent with the concentrations that enhanced phagocytic activity of PMNs.

The above data show that brief treatment (in our study, G. lucidum treatment for $7.5 \mathrm{~min}$ had the best effects) with the sporoderm-broken germinating spores of G. lucidum activates p38 MAPK in a dosedependent manner. The results indicate that $G$. lucidum acts on the p38 MAPK pathway in a dosedependent manner.

The data presented support the hypothesis that G. lucidum exerts dose-dependent stimulatory effects on human PMNs and acts via the p38 MAPK pathway. These results confirm the results of previous studies in which G. lucidum enhanced PMN phagocytic activity via the p38 MAPK pathway. We hope that these results can be applied in people with chronic diseases related to inflammation in our future research. However, the optimal concentration of G. lucidum may be related to the method of extraction and the relative proportions of the many components in the extract. Furthermore, it is not clear that G. lucidum has the same effect when administered orally to humans.

The major disadvantage in this study was that our sample may not have been representative, because the sample size was small and limited to young healthy adults. Hence, selection bias is inevitable. Owing to the limited case number, this study can only serve as a preliminary study. Further more comprehensive randomized studies with larger sample sizes are needed. The time-course effects of G. lucidum on PMN phagocytic activity, studies of the potential mechanisms of the action of G. lucidum via other protein tyrosine kinases such as the Src family kinases, studies of more purified components of G. lucidum extract, and in vivo studies, will also be considered in our future research.

\section{Acknowledgements}

This study was supported by a grant from the National Science Council, Taiwan, (92-2320-B182A-010). We thank Chang Gung Biotechnology Co. Ltd. Taipei, Taiwan for their donation of $G$. lucidum. 


\section{REFERENCES}

1. El-Mekkawy S, Meselhy MR, Nakamura N, Tezuka Y, Hattori M, Kakiuchi N, Shimotohno K, Kawahata T, Otake T. Anti-HIV-1 and anti-HIV-1-protease substances from Ganoderma lucidum. Phytochemistry 1998;49:16517.

2. Kim YS, Eo SK, Oh KW, Lee C, Han SS. Antiherpetic activities of acidic protein bound polysaccharide isolated from Ganoderma lucidum alone and in combinations with interferons. J Ethnopharmacol 2000;72:451-8.

3. Su CY, Shiao MS, Wang CT. Potentiation of ganodermic acid $\mathrm{S}$ on prostaglandin E1-induced cyclic AMP elevation in human platelets. Thromb Res 2000;99:135-45.

4. Song YS, Kim SH, Sa JH, Jin C, Lim CJ, Park EH. Antiangiogenic and inhibitory activity on inducible nitric oxide production of the mushroom Ganoderma lucidum. J Ethnopharmacol 2004;90:17-20.

5. Fujita R, Liu J, Shimizu K, Konishi F, Noda K, Kumamoto S, Ueda C, Tajiri H, Kaneko S, Suimi Y, Kondo R. Anti-androgenic activities of Ganoderma lucidum. J Ethnopharmacol 2005;102:107-12.

6. Liu X, Yuan JP, Chung CK, Chen XJ. Antitumor activity of the sporoderm-broken germinating spores of Ganoderma lucidum. Cancer Lett 2002;182:155-61.

7. Lin SB, Li CH, Lee SS, Kan LS. Triterpene-enriched extracts from Ganoderma lucidum inhibit growth of hepatoma cells via suppressing protein kinase $\mathrm{C}$, activating mitogen-activated protein kinases and G2-phase cell cycle arrest. Life Sci 2003;72:2381-90.

8. Sliva D, Labarrere C, Slivova V, Sedlak M, Lloyd FP Jr, Ho NW. Ganoderma lucidum suppresses motility of highly invasive breast and prostate cancer cells. Biochem Biophys Res Commun 2002;298:603-12.

9. Lu QY, Jin YS, Zhang Q, Zhang Z, Heber D, Go VL, Li FP, Rao JY. Ganoderma lucidum extracts inhibit growth and induce actin polymerization in bladder cancer cells in vitro. Cancer Lett 2004;216:9-20.

10. Wang SY, Hsu ML, Hsu HC, Tzeng CH, Lee SS, Shiao MS, Ho CK. The anti-tumor effect of Ganoderma lucidum is mediated by cytokines released from activated macrophages and $\mathrm{T}$ lymphocytes. Int $\mathrm{J}$ Cancer 1997;70:699-705.

11. Chien CM, Cheng JL, Chang WT, Tien MH, Tsao CM, Chang YH, Chang HY, Hsieh JF, Wong CH, Chen ST. Polysaccharides of Ganoderma lucidum alter cell immunophenotypic expression and enhance CD56+ NKcell cytotoxicity in cord blood. Bioorg Med Chem 2004;12:5603-9.

12. Guo L, Xie J, Ruan Y, Zhou L, Zhu H, Yun X, Jiang Y, Lü L, Chen K, Min Z, Wen Y, Gu J. Characterization and immunostimulatory activity of a polysaccharide from the spores of Ganoderma lucidum. Int Immunopharmacol 2009;9:1175-82.
13. Zhang J, Tang Q, Zhou C, Jia W, Da Silva L, Nguyen LD, Reutter W, Fan H. GLIS, a bioactive proteoglycan fraction from Ganoderma lucidum, displays anti-tumour activity by increasing both humoral and cellular immune response. Life Sci 2010;87:628-37.

14. Schett G, Zwerina J, Firestein G. The p38 mitogen-activated protein kinase (MAPK) pathway in rheumatoid arthritis. Ann Rheum Dis 2008;67:909-16.

15. Yang SH, Hong CY, Yu CL. The stimulatory effects of nasal discharge from patients with perennial allergic rhinitis on normal human neutrophils are normalized after treatment with a new mixed formula of Chinese herbs. Int Immunopharmacol 2002;2:1627-39.

16. Yamamori T, Inanami O, Nagahata H, Cui Y, Kuwabara M. Roles of p38 MAPK, PKC and PI3-K in the signaling pathways of NADPH oxidase activation and phagocytosis in bovine polymorphonuclear leukocytes. FEBS Lett 2000;467:253-8.

17. Chen HS, Tsai YF, Lin S, Lin CC, Khoo KH, Lin CH, Wong $\mathrm{CH}$. Studies on the immuno-modulating and antitumor activities of Ganoderma lucidum (Reishi) polysaccharides. Bioorg Med Chem 2004;12:5595-601.

18. Jeurink PV, Noguera CL, Savelkoul HF, Wichers HJ. Immunomodulatory capacity of fungal proteins on the cytokine production of human peripheral blood mononuclear cells. Int Immunopharmacol 2008;8:1124-33.

19. Liu W, Wang H, Pang X, Yao W, Gao X. Characterization and antioxidant activity of two low-molecular-weight polysaccharides purified from the fruiting bodies of Ganoderma lucidum. Int J Biol Macromol 2010;46:451-7.

20. Cao LZ, Lin ZB. Regulation on maturation and function of dendritic cells by Ganoderma lucidum polysaccharides. Immunol Lett 2002;83:163-9.

21. Lin YL, Liang YC, Lee SS, Chiang BL. Polysaccharide purified from Ganoderma lucidum induced activation and maturation of human monocyte-derived dendritic cells by the NF- $\mathrm{KB}$ and p38 mitogen-activated protein kinase pathways. J Leukoc Biol 2005;78:533-43.

22. Hsu MJ, Lee SS, Lin WW. Polysaccharide purified from Ganoderma lucidum inhibits spontaneous and Fas-mediated apoptosis in human neutrophils through activation of the phosphatidylinositol 3 kinase/Akt signaling pathway. J Leukoc Biol 2002;72:207-16.

23. Dudhgaonkar S, Thyagarajan A, Sliva D. Suppression of the inflammatory response by triterpenes isolated from the mushroom Ganoderma lucidum. Int Immunopharmacol 2009;9:1272-80.

24. Chung HJ, Lee HS, Shin JS, Lee SH, Park BM, Youn YS, Lee SK. Modulation of acute and chronic inflammatory processes by a traditional medicine preparation GCSB-5 both in vitro and in vivo animal models. J Ethnopharmacol 2010;130:450-9.

25. Kolb H, Mandrup-Poulsen T. The global diabetes epidemic as a consequence of lifestyle-induced low-grade inflammation. Diabetologia 2010;53:10-20. 
26. Boucher FR. Metabolic disorders in heart diseases with an inflammatory background. Cardiovasc Res 2010;87:4035.

27. Kudo H, Kai H, Kajimoto H, Koga M, Takayama N, Mori T, Ikeda A, Yasuoka S, Anegawa T, Mifune H, Kato S, Hirooka Y, Imaizumi T. Exaggerated blood pressure variability superimposed on hypertension aggravates cardiac remodeling in rats via angiotensin II system-mediated chronic inflammation. Hypertension 2009;54:832-8.

28. Coussens LM, Werb Z. Inflammation and cancer. Nature 2002;420:860-7.

29. Brumell JH, Burkhardt AL, Bolen JB, Grinstein S.
Endogenous reactive oxygen intermediates activate tyrosine kinases in human neutrophils. J Biol Chem 1996;271:1455-61.

30. Hsu MJ, Lee SS, Lee ST, Wan-Wan Lin WW. Signaling mechanisms of enhanced neutrophil phagocytosis and chemotaxis by the polysaccharide purified from Ganoderma lucidum. Brit J Pharmacol 2003;139:289-98.

31. Heuertz RM, Tricomi SM, Ezekiel UR, Webster RO. Creactive protein inhibits chemotactic peptide-induced p38 mitogen-activated protein kinase activity and human neutrophil movement. J Biol Chem 1999;274:17968-74. 


\section{靈芝破壁狍子萃取物 \\ 藉由 $\mathrm{p38}$ 絲裂原活化蛋白激酶路徑活化嗜中性白血球}

許珮毓 ${ }^{1}$ 陳俊良 ${ }^{1,2}$ 陳星諭 ${ }^{1}$ 楊賢鴻 ${ }^{1,2}$

背 景：靈芝 (Ganoderma lucidum, G. lucidum) 在傳統中醫被用來調節人體免疫已有數千年的 歷史, 一般認爲靈芝可藉由活化人體嗜中性白血球來達到增強免疫的功能, 然而對 於露芝作用在嗜中性白血球上的確切機轉並不明確。本實驗在於研究露芝活化嗜中 性白血球的分子生物機轉。

方 法：評估霝芝破壁狍子的萃取物對人體嗜中性白血球吞噬作用強度的影響, 然後加入 p38 絲裂原活化蛋白激酶 (p38 mitogen-activated protein kinase, p38 MAPK) 抑制劑於存在 靈芝破壁狍子萃取物的嗜中性白血球中, 探討 $\mathrm{p} 38$ 絲裂原活化蛋白激酶抑制劑對嗜 中性白血球吞噬功能的影響, 接著評估靈芝破壁狍子萃取物對 p38 絲裂原活化蛋白 激酶功能的影響。

結 果: 從本實驗中我們證實了靈芝破壁狍子的萃取物對嗜中性白血球吞噬功能有增強的效 果, 且與劑量相關, 在加入 p38 絲裂原活化蛋白激酶抑制劑後吞噬的功能會被減 弱。此外, 霝芝破壁狍子的萃取物對 p 38 絲裂原活化蛋白激酶的功能也有增強的效 果, 一樣與劑量相關。

結 論: 從以上的實驗結果證實了霝芝破壁胞子的萃取物可藉由 $\mathrm{p} 38$ 絲裂原活化蛋白激酶路 徑活化嗜中性白血球以調節免疫功能, 這些結果可智助傳統中醫醫師在臨床上的使 用。

(長庚醫誌 2012;35:140-7)

關鍵詞：傳統中醫，靈芝，嗜中性白血球，p38 絲裂原活化蛋白激酶

1長庚醫療財團法人桃園長庚紀念醫院 中醫部 ; 長庚大學 醫學院 2中醫學系

受文日期：民國100年2月10日；接受刊載：民國100年9月29日

通訊作者: 楊賢鴻醫師, 長庚醫療財團法人桃園長庚紀念醫院 中醫部。桃園縣333龜山鄉舊路村頂湖路123號。

Tel: (03)3196200轉2611; Fax: (03)3298995; E-mail: dryang@ cgmh.org.tw 